\title{
17
}

\section{Whatever happened to Western separatism?}

\section{Apolosi Bose and Jon Fraenkel}

Political parties hostile to the dominance of the eastern chiefly élite in national politics have regularly emerged in western Viti Levu. ${ }^{1}$ Most have emphasized the economic centrality of the west as the source of most of the country's sugar, gold, timber and tourism earnings. ${ }^{2}$ Twice since independence, prime ministers from the west have been deposed by coups (Dr Timoci Bavadra in 1987 and Mahendra Chaudhry in 2000), fuelling western perceptions of regional injustice. The Party of National Unity (PANU) gained four seats at the 1999 poll and became part of the short-lived Labour-led People's Coalition until the coup of 19 May 2000. At the election of 2001, the emergence of a new rival western-based party, the Bai Kei Viti (BKV), split the western Fijian vote and enabled the governing Soqosoqo Duavata ni Lewenivanua (SDL) to take all the western Fijian communal constituencies. PANU hoped to avoid a repeat of that outcome. Yet, in 2006, the SDL again took all of the western Fijian communal seats. This chapter looks at the background to the SDL's triumph in the west, and at the shifting politics in Ba Province.

Ba Province extends around the north-western side of Viti Levu, and includes Nadi town, Lautoka city, Ba and Tavua (see Map 17.1). It covers a region of fertile cane fields, from where sugar is transported to the Lautoka and Rarawai sugar mills. It also includes the Nadi international airport, the main gateway for tourist arrivals into the country and a key crossroads for transPacific air transport. To the north, Ba Province includes the scattered islands 


\section{Map 17.1 The Tikina Makawa of Ba Province}

\section{THE TIKINAS OF BA PROVINCE}

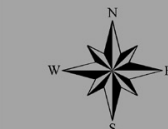

Yasawa

The Republic of Fiji Islands

Viwa

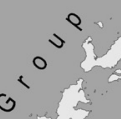

Nacula
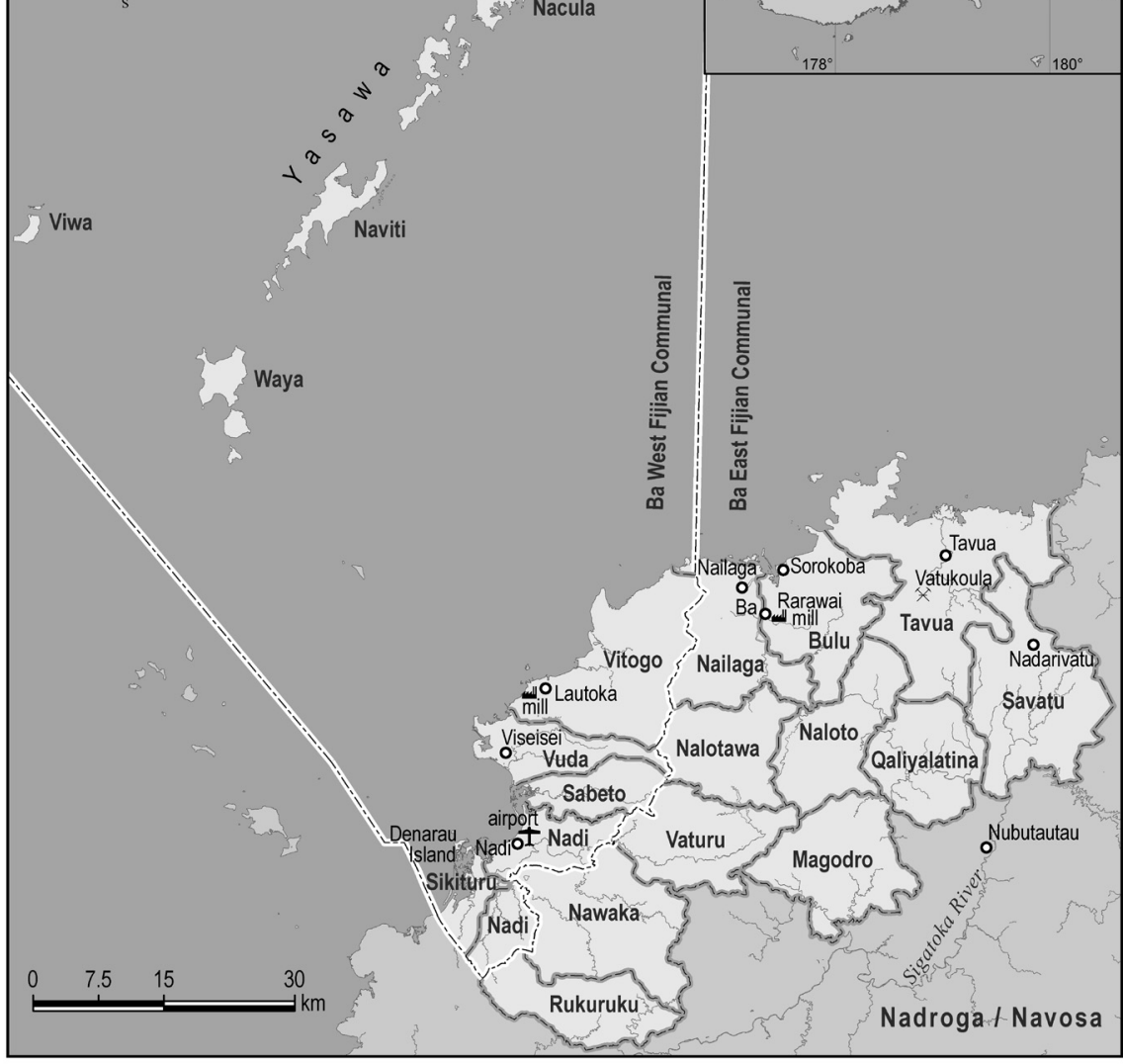

Naviti

Source: Pacific Institute of Advanced Studies in Development and Governance (PIAS-DG) Mapping Database, University of the South Pacific, Suva. 
of the Yasawas, a major destination for tourists. Close to Nadi, the island of Denarau features a major golf course, a high-end residential development and several internationally renowned hotels, which are regularly used as venues for international conferences. In addition, the province has rich forestry resources (particularly pine and indigenous hardwoods), mostly in the interior tikinas of Savatu, Qaliyalatina and Naloto. The country's only operating goldmine is at Vatukoula in Tavua. Ba Province is easily the richest province in terms of natural resources in Fiji, as well as being the country's biggest foreign exchange earner.

Political power, however, has been traditionally concentrated in Fiji's east. Leading 19th century chiefs, such as Ratu Seru Cakobau and Enele Ma'afu were, respectively, from Bau Island, off Viti Levu's eastern coast, and the Lau group, further east towards Tonga. Their 20th century successors, Ratu Sir Lala Sukuna and Ratu Sir Kamisese Mara, were also from the eastern islands. The country's great Fijian confederacies (matanitu), which play an important role in the decision-making of the Bose Levu Vakaturaga (BLV - Great Council of Chiefs), are Kubuna, Burebasaga and Tovata, all of which are centred on the eastern part of Fiji. The western part of Viti Levu is nominally divided between Burebasaga, at the helm of which stand the Rewa chiefs, and Kubuna, the confederacy centred on Bau Island, off the eastern coast of Viti Levu. This partitioning of the west reflected, first, the establishment of larger chiefdoms in the east during the late 18th and early 19th centuries, and the greater fractiousness of tribes in the west. Second, it reflected the colonial development of a neo-traditional order, which brought the west under the provincial controls of the Fijian administration. Aspirations for a separate western confederacy, the Yasayasa Vaka Ra, have at times proved politically significant, but this has never formally materialized or been accepted by the Great Council of Chiefs.

The political marginalization of the west resulted in a long history of dissent and revolt. ${ }^{3}$ Warfare from around 1867 was between coastal and interior groups, and was triggered by land sales and European settlement. ${ }^{4}$ Clashes at the upper reaches of the $\mathrm{Ba}$ and Sigatoka rivers were the most difficult to subdue. In 1873, European officers acting for the Cakobau government (1871-74) led around 160 trained native troops and a larger number of auxiliaries through Magodro to seize the mountain stronghold of Nubutautau, taking around a thousand prisoners, 
many of whom were forcibly relocated away from their interior villages. ${ }^{5}$ After cession, British Governor Arthur Gordon led a military campaign to suppress uprisings in the Ba interior in 1876 (known locally as the Valu ni Lotu - the 'Church War'). ${ }^{6}$ The 1892 separation of Colo North' from Colo West and Colo East, with a new headquarters at Nadarivatu, was in part intended to 'lessen dangerous combines' and isolate the 'Tuka' movement of Navosavakadua. ${ }^{8}$ In all the interior provinces, including Colo West and Colo East as well as Colo North, villagers were, after the advent of colonial rule, without single rulers, and as a result fell under the control of European district administrators. ${ }^{9}$ Hostility to the new order also festered on the grounds that $\mathrm{Ba}$ and Nadi chiefs had not been represented amongst those who had signed the Deed of Cession in 1874. Indeed, 300,000 acres of land in the interior tikina of Magodro had been formally appropriated in the schedule attached to the Deed, although the appropriation was later rejected by the colonial administration. ${ }^{10}$ In 1945, Colo North, like the other inland provinces, was incorporated into the coastal provinces. ${ }^{11}$

Dissident movements also emerged in 20th century western Viti Levu, sometimes as echoes of the 'Tuka' movement. ${ }^{12}$ Apolosi R. Nawai, from Narewa in Nadi, commenced the Viti Kabani (Fiji Company) in 1912-13 with the objective of challenging colonial control over commerce, starting a movement that spread eastwards to Tailevu and Rewa. ${ }^{13}$ In the post-colonial period, Fijian political leaders in Ba have sometimes aligned themselves along provincial or regional, rather than ethnic, lines, and found common cause with local IndoFijian leaders. ${ }^{14}$ For many left-wing intellectuals, the predominantly Indian support base of the Fiji Labour Party (FLP) could potentially be extended by alliances with Fijians in the west. ${ }^{15}$ Labour's Dr Timoci Bavadra, from Viseisei village, briefly became prime minister in 1987 before being dislodged by a military coup in May. For many in the west, the overthrow of that government was yet another attempt by Fiji's eastern rulers to retain power and authority.

The population of $\mathrm{Ba}$, as recorded at the 1996 census, was 212,197, making this easily the most populous province in the country. The majority of the population is Fiji Indians (63.9 per cent). Ethnic Fijians have just over half that share (32.9 per cent). ${ }^{16}$ As a result, the major Indian party, the FLP, has been able to win all seven of the Ba-located open constituencies at the elections of 1999, 2001 and 2006. ${ }^{17}$ Including also communal constituencies, 
Ba Province controls just over a quarter (18) of the seats in the 71-member parliament. Western-based Fijian parties have, in earlier years, been centred on provinces other than Ba. The 1960s Fijian National Party and the 1980s Western United Front, for example, had their strongholds in the neighbouring Nadroga province. Since the 1990s, however, emergent western parties, such as the All National Congress (ANC) and PANU, have been Ba-based, and relied critically on the sponsorship of the Ba Provincial Council.

The Ba Provincial Council brings together the region's 21 tikinas, each of which has a chiefly representative and a tikina representative (the total membership is 42). Politics on the council are influenced by the fact that there is no single ascendant paramount chief, unlike provinces in most other parts of the Fiji group. ${ }^{18}$ The tikina of Vuda has occasionally claimed pre-eminence. Its chiefs have assumed leading positions in national affairs. In the early post-independence years, Tui Vuda Ratu Sir Josaia Tavaiqia was a minister in successive Alliance governments (1977-87) and in the post-1987 coup Military and Civilian Council. He became vice president from 1993 until he passed away in 1997.The Vuda title and the vice presidency then passed to Ratu Josefa Iloilo, who acceded to the presidency in 2000. Vuda's claims are also strengthened by the Fijian legend that the first people to arrive in Fiji disembarked at Vuda Point, where a popular resort called 'First Landing' now exists. When the British royal family visits Fiji, they regularly visit Vuda. Yet, this claim to pre-eminence can rest uncomfortably in neighbouring tikinas, such as Vitogo, Nadi and Sabeto. Tavua's leading chief, Ratu Ovini Bokini, is fond of saying in some Provincial Council Meetings that, in Ba Province: ' $x o$ da na momo ni Ba dei tautauvata, xei tixai tla xei cecere tatla qa tixai tla xei te momo sewa' ('We, the chiefs in $\mathrm{Ba}$, are equal in rank'). This type of appeal to an egalitarian distribution of authority amongst western leaders is sometimes used by the current chairman of the Ba Provincial Council to quell any push for pre-eminence. ${ }^{19}$

The chiefs of the coastal tikinas are the most wealthy and powerful within the province. They are recipients of large agricultural and commercial rents from the Native Land Trust Board (NLTB), and have access to capital. Some, like the Tui Nawaka and the Saunaka chiefs, have provided residential plots for resettlement on the outskirts of Nadi, where displaced Indians have established hundreds of new homes without obtaining NLTB leases (via 'vakavanua' arrangements). ${ }^{20}$ The interior chiefs tend to be less prominent, despite their important role in 
political campaigning. Their tikinas are nowadays sparsely populated, and some villages are so remote that people do not understand the Bau dialect, the lingua franca across most parts of the Fiji group. They are considerably poorer than their coastal counterparts, owing to the hilly terrain and the paucity of access roads to regions such as Vaturu, Nalotawa and Naloto. During provincial council meetings, tikina representatives from the interior of the province often lament the lack of access to markets, and the difficulties of bringing sugar cane to the Lautoka or Rarawai mills. Interior peoples remain predominantly subsistenceoriented, although cash incomes are secured by migrating to cut cane in the coastal districts or by sales of inland produce in urban markets.

The five tikinas of the Yasawas also have a less central influence in the affairs of the Ba Provincial Council than do the Viti Levu coastal chiefs. The islands do not have the land resources of the mainland peoples. Their main sources of income are fish, yams, and subsistence agriculture, as well as, increasingly, tourism. The Yasawa group has, historically, done well in winning national scholarships. Prominent officials, such as the CEO in the Ministry of Agriculture, the Commissioner Northern and the Commissioner Eastern and the country's Catholic Archbishop, come from the group. Yet, the islands themselves remain under-developed. There is only one secondary school in the Yasawas, there are difficulties with the water supply and, although every island has a health centre, there is no hospital. Linkages between the Yasawas and $\mathrm{Ba}$ are sometimes contested. Questions have been raised at the council about the size of the Yasawa contribution to the tikina levies, and there have been occasional calls to re-establish the five island tikinas as a separate province. ${ }^{21}$ There have also been separatist commercial aspirations; an islander initiative in the early 1990s was the Asayawa Holding Company Limited, established before Ba Provincial Holdings Company Limited (BPHCL). The former was shelved in 1994, in response to appeals for a more unified provincial company. $\mathrm{Ba}$ Holdings, the commercial arm of the Ba Provincial Council, was registered in 1995..$^{22}$ By 2006, BPHCL had interests in shipping, property, hardware and a satellite television company (Pacific Broadcasting Services), and ran the Ba Province Secondary School on behalf of the council.

Animosities between rival chiefs in Ba Province, often centering on land disputes, exert a critical influence over local political alignments. The dispute 
between the Tui $\mathrm{Ba}$ (Bulu) and the Tui Ba (Nailaga) blew up in the 1860s and centres on rival claims to lands on the border between these neighbouring regions. ${ }^{23}$ In the early colonial days, the headquarters of the provincial administration was at Vitogo village, until it was brought to Lautoka. Many Vitogo people believed that this was at the instigation of the Viseisei chiefs (of Vuda), and that Viseisei peoples had also otherwise been favoured under colonial rule. When Viseisei's Ratu Tevita Moemeodonu took control of BPHCL in the wake of the 2006 election, amongst those who stormed the Rogorogoivuda building in opposition to the takeover, people from the vanua of Vitogo (or those who had blood ties to Vitogo) figured prominently. Many had been workers at the company under the previous administration, and had been sacked by Ratu Moemoedonu. Claims by the people of Sabeto to ownership of the land around Nadi airport have been vigorously contested by the Saunaka people (from within the Nadi tikina), some of whom benefit greatly from rental incomes from land and commercial interests at Nadi Airport. Whatever the characteristic political frictions of the day, some of the Saunaka chiefs will tend to be on one side, and some of the people of Sabeto on the other side.

Fissions are as common within as between tikinas. The Sabeto peoples once lived in fortified villages up in the range separating Nadi and Lautoka, until the Cakobau government troops forced them to burn their villages and move down to the coast. ${ }^{24}$ Apisai Tora, a veteran trade unionist and instigator of PANU, is the head of one of the yavusas within Sabeto, but had major differences with the Tui Sabeto, who was a supporter of Rabuka's 1992-99 Soqosoqo ni Vakavulewa ni Taukei (SVT) administrations and later of Qarase's SDL governments. Tavua's Ratu Ovini Bokini had been a cabinet minister in the SVT government, but was sacked in the mid-1990s after he was charged with several offences relating to official bribery, including complicity in the National Bank of Fiji fraud case. ${ }^{25}$ This also contributed to the diminishing respect he commanded within the anyway large and fractious Tavua area. Saunaka landowners have also fallen out over the Westfield City development near the airport. A long-running dispute over the Tui Nadi title stems from an incident many decades ago when the title was rightfully to have passed to a small child, but was instead given to the uncle from a collateral $i$-tokatoka (sub-clan). Today, the title includes rights to 
earnings from the Denarau development, believed to amount to more than a million Fiji dollars a year. The Native Lands Commission clearly established the genuine title-holder, but local political allegiances were more uncertain. While the dispute remains unresolved, royalties and rental incomes are frozen, and held by the NLTB on behalf of the rightful owner. The heads of the two rival $i$-tokatoka invariably support different parties, in the hope of using modern political triumphs to settle these deeper disputes. The continued fractiousness of the sub-clans arising from support for rival candidates for the Nadi title often spills into backing for different political parties or candidates.

Intra-Fijian conflicts are also reinforced by chiefly linkages with the big Indian companies that operate in Ba Province, which themselves have internecine squabbles that at times curiously resemble those among Fijian landowners. Top Gujarati executives are sometimes humorously called 'Guja-ratus', appending the Fijian honorific 'ratu'. These companies have benefited from the affirmative action programs of the post-1987 coup era, cashing in by way of joint ventures with nouveau riche Fijians. Many of them originated from Ba town. ${ }^{26}$

Saunaka landowners have a joint venture with Motibhai Co. Ltd., responsible for the Prouds duty-free store at Nadi Airport. Executive chairman Mahendra Motibhai Patel is close to the Qarase government, and doubles as the chairman of Post Fiji. Motibhai Co. Ltd also had close relations with the Mara and Rabuka governments, which for many years enabled the company to secure important commercial concessions. The Tappoo Group of Companies is the other major duty-free chain at Nadi Airport, although it has been less favoured by Fijian governments. Rumours circulating within the business community alleged that Tappoo had given $\$ 50,000$ to the FLP for the 2001 election campaign.

Business rivalries amongst leading Gujarati firms are often sparked or reinforced by expansion into each other's traditional areas. The wholesale distributor and flour manufacturing firm, Punjas, is opposed to Tappoo because of the latter's diversification from retail of luxury goods into foodstuffs and spices, traditionally the specialities of Punjas. Closest to the BPHCL is the hardware retail giant Vinod Patel; the two have a joint venture called Bavin Ltd. Vinod Patel managing director is Bachubhai Patel, another close associate of Prime Minister Qarase. Company chair Vinod Patel was mayor of Ba town and then stood successfully for the National Federation Party (NFP) in 1992 
and 1994. Because of their stiff competition in the hardware market, R.C. Manubhai, yet another Ba-originated firm, is a great rival to Vinod Patel, and the two often engage in behind-the-scenes backbiting (' $k u c h$ kuch').

For many, but not all, of these Indian business leaders, the Chaudhry government's socialist policies and the threat of tax probes encouraged alliances with the Fijian opposition. Chaudhry himself, and the Fiji Military Forces' Lieutenant-Colonel Viliame Seruvakula, went so far as to allege that some Indian business leaders had been involved in backing the coup in May 2000. ${ }^{27}$ Yet, Chaudhry also had friends in high business circles, which were in part a legacy of the alliance he forged with President Ratu Mara at the time of his 1999 election victory - such friends included, for example, Mahendra Patel, RC Manubhai and other non-Gujarati figures such as Rajendra Prasad. ${ }^{28}$ Most of the big Gujarati firms played it safe in 2006 by giving tacit support to both sides. There were also claims that the FLP was proactively seeking the support of Gujarati businessmen in the lead-up to the 2006 general election. When the FLP launched its campaign for the 2006 election in Ba, Vinod Patel, despite his long association with the NFP, was one of the chief guests.

Although links with the Indian companies have grown in commercial importance over recent decades, the dynamics of western Viti Levu-based indigenous party formation have centred primarily on rivalries amongst the Fijians themselves.

Prior to the 1999 general election, with the support of the Ba Provincial Council, a group of prominent western politicians who were dissatisfied with the Rabuka-led SVT government, formed PANU. The SVT had convincingly won all three communal seats in Ba Province during the 1994 election. ${ }^{29}$ In 1995, Prime Minister Rabuka had embarked on a constitutional review in cooperation with NFP leader Jai Ram Reddy. When PANU was formed, a major element of its case against the SVT was that it had 'sold out the Fijians' by passing the 1997 Constitutional Amendment Act. ${ }^{30}$ Ba politicians believed that, by establishing a new party, they might emerge victorious in the province's 18 seats, thus effectively controlling 25 per cent of the House of Representatives. Sabeto chief Apisai Tora played an important role in the party's formation, and became the PANU general secretary. ${ }^{31}$ Another major player was Ratu Sairusi Nagagavoka, the Tui Ba (Bulu) and one of the largest landowners in the 
province. The Vice President and Tui Vuda, Ratu Josefa Iloilo, was appointed patron of the party. ${ }^{32}$ The SVT strongly challenged this appointment, arguing that, as stipulated in the constitution, the Office of the President is a 'Symbol of Unity of the Nation', and should not therefore be identified with any political party. As a result, Ratu Josefa Iloilo resigned from PANU.

In the lead-up to the 1999 elections, PANU at first courted a coalition arrangement with the SVT, but eventually signed a memorandum of understanding with the FLP. This was an odd coalition as the Labour Party had been critical of the NFP's close relationship with the Rabuka-led SVT Government, labelling it a 'sell out'. Parties from different ends of the political spectrum were rallying together against those which had reached a cooperative arrangement at the centre of Fiji politics. Cracks soon appeared in the marriage between the FLP and PANU. Part of the agreement between the two had been to avoid fielding parallel candidates in certain constituencies. After the FLP stood Pradhman Raniga against Apisai Tora for the Nadi Open constituency, antagonism emerged between the Sabeto politician and Mahendra Chaudhry. A year after the election, Tora was one of the leaders of the revived taukei movement of ethnic nationalist Fijians that marched through the streets of Suva while George Speight seized control of Fiji's parliament.

Tora's newfound antipathy to Chaudhry and the FLP after the May 1999 election led to a realignment within the board of the BPHCL. At the time,

Table 17.1 Western Fijian parties' shares of the first preference Fijian communal vote in target constituencies, 1999-2006 (per cent)

\begin{tabular}{|c|c|c|c|c|}
\hline & \multirow{2}{*}{$\begin{array}{c}1999 \\
\text { PANU }\end{array}$} & \multicolumn{2}{|c|}{2001} & \multirow{2}{*}{$\begin{array}{c}2006 \\
\text { PANU }\end{array}$} \\
\hline & & PANU & BKV & \\
\hline Ba East Fijian Communal & 52.5 & 25.3 & 19.8 & 31.6 \\
\hline Ba West Fijian Communal & 49.2 & 14.8 & 36.2 & 7.8 \\
\hline Northwest Urban Fijian Communal & 43.1 & 3.9 & 13.1 & - \\
\hline Ra Fijian Communal & 31.7 & 11.3 & 6.4 & - \\
\hline Total Fijian Communal & 9.6 & 2.9 & 4.7 & 2.0 \\
\hline Total Open constituencies & 3.9 & 0.8 & 1.3 & 0.5 \\
\hline
\end{tabular}

Notes: PANU = Party of National Unity; BKV = Bai Kei Viti.

Source: Basic data from the database of the Pacific Institute for Advanced Studies in Development and Governance, University of the South Pacific, Suva. 
the company was run by SVT minister Isimeli Bose. Tora had previously been highly critical of the running of the company. Together with PANU president Ratu Sairusi Nagagavoka, he had filed a writ in the High Court against the company and Bose. Yet, in the wake of the election-related fall-out with Chaudhry, Tora's relationship with the BPHCL management improved, while his relationship with Ratu Sairusi soured. The Bulu chief remained loyal to Mahendra Chaudhry. In one of the BPHCL debates in the wake of the 1999 general election, he described Chaudhry as 'Kai Ba', adding that this was the first time that Bulu had a direct line to a prime minister.

PANU obtained four Fijian communal seats at the 1999 election. In addition to the two Ba seats, Eloni Goneyali took the Ra Fijian seat and Akanisi Koroitamana took the Northwest Fijian urban seat. The two Ba MPs entered the People's Coalition cabinet. Meli Bogileka, from Yasawa Island, served as the Minister for Civil Aviation; Ponipate Lesavua, a native of Nawaka Village in Nadi and a former policeman, became Minister for Youth and Sports. Like the FLP, PANU was assisted by advisors from the Australian Labor Party at the 1999 polls.

Land issues were always going to be difficult for the new Labour-led government, and were of particular importance for the NLTB rent-dependent chiefs in this sugar-rich province. Prior to the polls, Ba landowners had issued a report rejecting renewal of land leases under the 1976 Agricultural Landlord and Tenants Act. ${ }^{33}$ Prime Minister Chaudhry, who also led the National Farmers Union, hoped for renewal of that legislation, and, failing that, needed land for resettlement of evicted Indian farmers. He sought to purchase land in the Qara region from close ally Ratu Sairusi Nagagavoka. The Tui Ba (Nailaga), Adi Senimili Cagilaba, challenged the sale, claiming the land belonged to her. The Ministry of Agriculture found in her favour. This renewed the long-running dispute between the Nailaga and Bulu chiefs, with Adi Cagilaba emerging as a vociferous critic of the Chandhry government. ${ }^{34}$ While in office, Chaudhry built a substantial bure for Ratu Sairusi at Sorokoba, clearly hoping to thereby cement that politically important alliance.

When PANU ministers toured the west seeking to forestall the threat posed by the revived taukei movement to the Chaudhry government, the two chiefs who opposed them were Tui Sabeto Ratu Kailova Mataitoga and Marama Tui $\mathrm{Ba}$ (Nailaga) Adi Senimili Cagilaba. ${ }^{35}$ 
The 2000 coup further exacerbated frictions amongst the Fijian chiefs in Ba Province, in ways that remained evident at the 2001 polls. Ratu Sairusi and the PANU ministers continued to support deposed Prime Minister Chaudhry, and threatened the formation of a breakaway state in western Viti Levu. A two-day meeting of western chiefs at the Mocambo Hotel that ended on 8 June 2000 appeared to have opted for the more moderate course of establishing a new confederacy. The day after the end of the Mocambo meeting, a delegation of western chiefs and politicians, including Vice President Ratu Josefa Iloilo, visited Speight's stronghold in parliament. Taukei leader Apisai Tora hugged Speight in a ceremony of mutual reconciliation that included Nadroga chief Ratu Osea Gavidi. Speight had held the chairs of both Fiji Pine and the Fiji Hardwood Corporation, but he had been sacked by the People’s Coalition government. Ratu Gavidi also had interests in timber exports. ${ }^{36}$ From that point onwards, Speight and his group forged a new alliance with western chiefs, calling on the military to pass a decree appointing Tui Vuda Ratu Josefa Iloilo president. ${ }^{37}$ This was a call that later drew Sabeto landowners to set up one of the many roadblocks around Viti Levu in early July 2000, a disturbance for which Apisai Tora was later convicted.

Tora entered the post-coup interim cabinet, and became Minister of Agriculture. Instead of joining the SDL in July 2001, however, he formed a new western Viti Levu-based party, the Bai Kei Viti, to challenge PANU in the latter's core Fijian communal constituencies (Ba West, Ba East, Ra and Northwest Fijian Urban). Both of these parties put the other as last preference, ensuring a mutual destruction of the two contending western-based parties. In both of the Ba Fijian communal constituencies, the SDL candidate leapfrogged from second place at the first count to win on the basis of transfers from one or other of the western parties. ${ }^{38}$

In the polarized post-coup circumstances, PANU's alliance with the FLP government took its toll. Ponipate Lesavua's first preference vote in Ba East fell from 52.5 per cent in 1999 to 25.3 per cent in 2001, while Meli Bogileka's vote in Ba West plummeted from 49.2 per cent in 1999 to 13.5 per cent in 2001. The Qarase government's triumph at the 2001 polls proved a disaster for both Ba-based parties. Ba Province no longer had any representation in the postelection SDL cabinet, although the SDL victor in Ba West, Tomasi Sauqaqa, became Assistant Minister for Health. Tora received a seat in the Senate as one 
of the Prime Minister's nominees; PANU's Ponipate Lesavua received an FLP seat in the Senate; and the Tui Nawaka, Ratu Apisai Naevo, was one of the Great Council of Chiefs' nominees to the Senate. Tavua chief Ratu Ovini Bokini also became chairman of the Great Council of Chiefs in July 2004. Although these were powerful positions, Ba politicians were no longer in core positions in government. In Ratu Mara's cabinets, there had always been ministers from Ba Province, and politicians from the west had also been strongly represented in the cabinets of Rabuka and Chaudhry.

Both PANU and the BKV were merely electoral vehicles, whose survival rested in part on the blessing and financial sponsorship of the Ba Provincial Council. In the wake of the 2001 election, Meli Bogileka broke away from PANU and formed a new People's National Party (PNP). In October 2004, efforts were made through the Ba Provincial Council to merge the BKV and PANU under the new PNP banner, but these met with resistance. Both PANU and the BKV had received loans from the Ba Provincial Council for their election campaigns, which had not been repaid. The PNP's latest request, backed by some who had also figured as executives in the BKV and PANU, was seen as use of a party front as a cash-raising mechanism. Some walked out of the meeting, not wanting to hear the PNP presentation. Ratu Ovini Bokini announced that the council would

Table 17.2 Election results in Ba Fiji Provincial Communal constituencies in 2006

$$
\text { Party }
$$

SDL

NFP

PANU

Ponipate Lesavua

Informal

Total registered

Ba West Fijian Provincial

Pauliasi Namua

Ratu Meli Q Saukuru

Taniela Wai

Meli Bogileka

Informal

Total registered
NFP

SDL

FLP

PANU
Votes

Per cent

60.4

732

8.0

2,888

31.6

1,067

10.4
11,836

257

9,211

1,156

883

1,143

15,348
2.2

80.0

10.0

7.7

9.0 
remain apolitical, and that people had a right to choose whatever political party they wanted. ${ }^{39}$ In the midst of the multiparty cabinet disputes in the law courts, which kept the polarization witnessed at the 2001 poll to the forefront of Fiji politics, PANU announced its own liquidation. Bogileka's PNP joined the 'Grand Coalition of Fijian Parties', spearheaded by former speaker Tomasi Vakatora. ${ }^{40}$ By contrast, Ponipate Lesavua, because he was an FLP nominee to the Senate, inevitably retained stronger links with the FLP leader.

Shortly before the 2006 poll, PANU was revived, again bringing together Ponipate Lesavua and Meli Bogileki as party leaders. ${ }^{41}$ Apisai Tora had retired from active politics, an event which also brought an end to the Bai Kei Viti, his brainchild for the 2001 election. PANU emerged again as a close ally of the FLP, with these two parties exchanging second preference votes.

Unlike in 2001, the SDL was able to take both of the Ba Fijian communal seats at the first count in 2006. In Ba West, Ratu Meli Saukuru, whose traditional title is the Taukei Navo, secured 9,211 votes, while PANU's Meli Bogileka obtained only 883 votes. Ratu Meli, yavusa head from the village of Dratabu in Nadi, acquired prominence owing to his achievements within the Methodist Church and as a businessman. He is a lay preacher and former vice president of the Methodist Church. He rose to prominence through the successful organization of the Methodist conference in Nadi in 2005, when he was chosen to head the church's investment company. He later accepted instead the SDL nomination in response to entreaties from within the church. Bogileka's support would have come from his home island of Yasawa, and perhaps also Vuda, but the Tui Sabeto was behind the SDL. The SDL must have also secured the bulk of the Nadi and Vitogo vote. ${ }^{42}$ Here, as throughout Fiji, the backing of the Methodist Church exerted a powerful influence on Fijian voting patterns.

In Ba East, the SDL faced a sterner challenge, but Paulo Ralulu, from Natunuku (Bulu Tikina), nevertheless easily won with 60 per cent of the first preference vote, defeating PANU's Ponipate Lesavua, who managed only 31.6 per cent of the vote. ${ }^{43}$ PANU would have received support from Ratu Sairusi Nagagavoka's area, including the village of Sorokoba and parts of the surrounding Bulu tikina, and perhaps from dissident areas in Tavua and from parts of Lesavua's home region of Nawaka. But even in his home region of Nawaka, the pro-SDL influence of the Tui Nawaka must have lost Lesavua votes. 
He also would have had negligible support in Nailaga, where retired nurse Adi Laite Kotoiwasa had succeeded her sister as Tui Ba (Nailaga), and staunchly backed the SDL. The Tui Tavua was behind the SDL, although that was a mixed blessing. In the Tavua by-election of January 2004, the SDL had fielded Ratu Ovini's son, Inoke Bokini. He was a human resources manager at Emperor Gold Mines at Vatukoula, a position that earned him some unpopularity amongst the Emperor employees and their family members that was reflected in the by-election outcome. He obtained only 28 per cent of the vote in a 45 per cent indigenous Fijian constituency. ${ }^{44}$ Ratu Ovini Bokini is nevertheless an important linkage for the SDL in the province. His mother is from the island of Bau, giving him vasu relations with that politically important island, and his wife is from the Prime Minister's island of Vanuabalavu in the Lau group.

Support for Labour and its allies had once been strong in interior tikinas like Magodro, where, in the 1980s, left-wing University of the South Pacific lecturer Simione Durutalo rallied many villagers in opposition to the SVT party supported by his father, the Tui Magodro. ${ }^{45}$ Durutalo's support had come largely from his mother's people, descended from the earlier taukei inhabitants who were related to the nearby Navosa peoples, whereas his father's family came from a line of conquering chiefs, related to the Tui Tavua and the Tui Ba (Nailaga). ${ }^{46}$ By the time of the 2006 election, both father and son had passed away, and the father's elder son had assumed the title. Most in Bukuya, the key Magodro village and tikina government station, backed the SDL in 2006, as did those in the surrounding villages. The former remoteness of the interior tikinas has been diminished by links with resettled interior peoples in coastal districts, which act as conduits for intermittent migration and, by and large, for the consolidation of support behind mainstream Fijian political parties.

The SDL's second triumph in western Viti Levu in 2006 signaled a watershed in Ba provincial politics. ${ }^{47}$ Not for the first time, the objective of a distinct western Fijian alliance with the big Indian-backed parties had been frustrated. As Nicholas Thomas found in 1990, internal divisions amongst western political leaders and cultural connections with other parts of the Fiji group mean that 'the thesis of a persistent east-west divide cannot be sustained in any strong form' ${ }^{48}$ Sixteen years later, new factors influenced political organization in the west. In particular, the development of the tourism industry and affirmative action 
programs had encouraged the emergence of a growing western indigenous élite, with strong connections with Gujarati big business. On balance, these ventures have tended to exacerbate, rather than soothe, rivalries among the coastal chiefs, which now play a greater political role than do dissident movements from the interior. That so much of the country's economic activity and foreign exchange earnings stem from the west probably enhances the potential for the emergence of western Viti Levu-based political organizations. Whether these will prove any more successful than their predecessors or whether the SDL will consolidate support in the west by giving this part of the country a greater stake in cabinet, remains to be seen.

\section{Notes}

1 The Western Democratic Party and Fijian National Party in the 1960s, the 1980s Western United Front, the early 1990s All-National Congress and the later 1990s Party of National Unity.

2 This chapter focuses on the post-1999 experience. For accounts of the earlier parties, see Alley, R.M. 1973. The Development of Political Parties in Fiji, PhD thesis, Victoria University of Wellington, Wellington; Norton, R. 1990. Race and Politics in Fiji, University of Queensland Press, Brisbane, 2nd edition, p.110; Lal, B.V. 1983. 'The Fiji general election of 1982; the tidal wave that never came', Journal of Pacific History, 18(1-2):139-44; Durutalo, A. 2006. 'Fiji: party politics in the post-independence period', in R. Rich, L. Hambly \& M. Morgan (eds) Political Parties in the Pacific Islands, Pandanus Books, Canberra, pp.165-83.

3 Drawing on oral evidence, Durutalo suggests that efforts by Bau chiefs to subjugate the interior peoples in western Viti Levu commenced as early as 1815-20 (Durutalo, S. 1985. Internal colonialism and unequal regional development : the case of western Viti Levu, M.A. thesis, University of the South Pacific, Suva, p.87. See also Sahlins, M. 2004. Apologies to Thucydides; Understanding History as Culture and Vice Versa, University of Chicago Press, Chicago \& London, pp.50-52).

4 Tanner, A. 1996. 'Colo Navosa local history and the construction of the region in the western interior of Vitilevu, Fiji', Oceania, 66(3):231-2.

5 Derrick, A. 1946. History of Fiji, Government Press, Fiji, [1974 reprint].

6 Routledge, D. 1985. Matanitu, The Struggle for Power in Early Fiji, Institute of Pacific Studies, University of the South Pacific, Suva, pp.154, 176.

7 Colo North or Colo Nadarivatu included the Tavua, Qaliyalatina and Savatu tikinas in presentday Ba Province (see Brewster, A.B. 1922. The Hill Tribes of Fiji, Seeley, Service \& Co Ltd, pp.284-5; Fiji Royal Gazette, 57, 19 December 1892).

8 Kaplan, M. 1990. 'Meaning, agency and colonial history: Navosavakadua and the Tuka movement in Fiji', American Ethnologist, 17(1):3-22; Tanner, 'Colo Navosa', p.245. The internal quote comes from the government agriculturalist W.L. Parham, cited in Tanner, 'Colo Navosa', p.246. The Tuka rebellions, led by Navosavakadua, spread across many parts of the Tavua-Rakiraki coast, as well as inland, and to many parts of Colo North (Robert Nicole, pers. comm. September 2006). 
9 MacNaught, T. 1982. The Fijian Colonial Experience: A Study of the NeoTraditional Order under British Colonial Rule prior to World War II, Pacific Research Monograph, 7, ANU, Canberra, p.4.

10 Derrick, History of Fiji, p.218n; Scarr, 1984. Fiji: A Short History, George Allen \& Unwin, Sydney \& London, p.75.

11 Royal Fiji Gazette, 10, 20 February 1945. Three tikinas in Colo North, Tavua, Qaliyalatina and Savatu, became part of Ba Province. In addition, Naloto and Magodro were separated from Colo West to become part of the new Ba province, while the rest of Colo West joined Nadroga/Navosa.

12 Kaplan, M. 1995. Neither Cargo nor Cult: Ritual Politics and the Colonial Imagination in Fiji, Duke University Press, p.120.

13 MacNaught. The Fijian Colonial Experience, p.78.

14 The Western Democratic Party joined forces with the Fijian National Party to form the National Democratic Party ahead of the 1966 polls, and together these joined A.D. Patel's Federation Party in 1967-68 to form the National Federation Party (Robert Norton, pers. comm. September 2006).

15 Durutalo, S. 1985. Internal colonialism and unequal regional development : the case of western Viti Levu, Fiji, MA thesis, University of the South Pacific, Suva; Robertson, R. \& Tamanisau, A. 1988. Fiji: Shattered Coups, Pluto Press, Sydney, p.17; but see Thomas, N. 1990. 'Regional politics, ethnicity and custom in Fiji', The Contemporary Pacific, 2(1).

16 Parliament of Fiji, Bureau of Statistics, 1996 Fiji Census of Population and Housing, General tables, Parliamentary Paper No. 43 of 1998, table 31. Ba, Tavua, Magodro, Yasawa/Nawaka, Nadi, Vuda, Lautoka City. Personal communication with Tikina Council representatives, Lautoka, August, 2006. Thanks to Paul Geraghty for assistance in conveying this in the Tavua dialect. The going rate usually entails start-up payments of $\mathrm{F} \$ 500$ and ongoing rentals of $\mathrm{F} \$ 150$ per annum for quarter acre sites.

21 Tikina representatives from Yasawas, Lautoka, pers. comm. August, 2006.

22 The late Tui Vuda Ratu Sir Josaia Tavaiqia had asked the Yasawans who were responsible for the establishment of Asayawa Holdings to concentrate first on a provincial company, hence the incorporation of BPHCL.

23 For the respective locations of Bulu and Nailaga, see Map 17.1. According to Adi Senimili Cagilaba, Tui Ba (Nailaga), the Bulu chiefs had historically used the title Tui Momo, but Ratu Sairusi's grandfather had obtained the Tui Ba title during Ratu Sukuna's years at the helm of the Fijian administration (The Fiji Times 4 January 2000; see Routledge. Matanitu, p.154; Scarr. Fiji: A Short History, p.62).

24 Routledge. Matanitu, pp.154, 176.

25 Pacific Media Watch/Pasifik Nius/Niuswire, 14 January 1999; PacNews 11 November 1997.

26 See Keith-Reid, R. 1992. 'The little town that's big in millionaires', Islands Business Pacific, 18(2); 'Giving Ba a fair go', The Review, April 1994.

27 The Fiji Times 24 April 2001; Fiji Daily Post, 20 June 2001.

28 We are indebted to Biman Prasad for highlighting this point.

29 Under the 1990 constitution, a block voting system was used in some Fijian communal constituencies, whereby eligible citizens had three votes for three MPs. In the case of larger provinces, like $\mathrm{Ba}$, there were three such seats. 

constitution. Apisai Tora had previously opposed Rabuka's selection by the Great Council of Chiefs as SVT leader, and he founded the All-National Congress to oppose the SVT at the 1992 and 1994 polls.

32 Ratu Josefa Iloilo grew up on Taveuni, and does not speak the Vuda dialect. This made his chairmanship of the Ba Provincial Council difficult, and made it easier for Apisai Tora to engineer the formation of PANU in 1998-99.

33 See the report of the findings in Parliament of Fiji, Parliamentary Paper No 4. of 1998, ALTA Task Force, Final Report, volume 2, pp.50-64.

34 Both Adi Senimili and Ratu Sairusi, as well as Ratu Kaliova Mataitoga, were Ba Provincial Council nominees on the Great Council of Chiefs. That they voted in different ways on issues such as the controversy over the renewal of the Agricultural Landlords and Tenants Act was, according to Adi Senimili, embarrassing for the Yasana of Ba (Personal communication between Apolosi Bose and Adi Senimili Cagilaba in 2002 at the Elixir Motel, Suva).

35 Fiji Daily Post, 19 April 2000.

36 See Wise, M. 'Unravelling a Web of Intrigue', The Fiji Times, 11 June 2000; Wilkinson, M. 'Mahogany Row', Sydney Morning Herald, 27 May 2000.

37 See Speight's nine-point proposal, published in The Fiji Times, 15 June 2000; see Fraenkel, J. 2000. 'The clash of dynasties and the rise of demagogues; Fiji's Tauri Vakaukauwa of May 2000', Journal of Pacific History 3(3).

38 In Ba East, the SDL's Epeli Seavula won at the fourth count with the margin of victory provided by BKV preferences. In Ba West, the SDL's Tomasi Sauqaqa won at the sixth count on the basis of PANU preferences.

39 Ba Provincial Council meeting, 26 October 2004; see also the reiteration of the stance by Roko Tui Ba Viliame Burenivalu in March 2006 (The Fiji Times, 3 March 2006).

In both constituencies, the FLP in fact received more first preference votes than PANU. This was only obvious in Ba West, where the FLP's Taniela Wai obtained 10 per cent. What the official figures do not show, however, is that more than half of Lesavua's votes were above-theline votes for the FLP. Since the FLP had no candidate, and since the FLP had listed Lesavua as their first preference, these 1,565 votes were transferred directly to Lesavua (data obtained from Master Tally Collection Sheet 0-39, Ba East Fijian, provided by Fiji Elections Office). Tavua, 17 January 2004, Fiji Government Gazette, 6 February 2004.

45 Under the SVT government, a mini-hyrdroelectric power station had been built near to Bukuya, supplying power to the village, and later developments - including the government's promised increase in family welfare payments - consolidated support behind the SDL.

46 Alumita Durutalo, pers. comm. 5 October 2006.

47 After failing to secure an FLP Senate nomination, PANU announced the end of its coalition with the FLP. Adi Ma Lutuciri, from the chiefly family of Saunaka village, was made vice president of the SDL at the party's post-election annual general meeting in September 2006.

48 Thomas, N. 1990. 'Regional politics, ethnicity and custom in Fiji', The Contemporary Pacific, 2(1):42. 